\title{
Relationships of Alizarin Test Scores with Somatic Cell Count in Bovine Milk
}

\author{
Baqdaulet Sadikov ${ }^{1, a}$, Savaş Atasever ${ }^{1, b, *}$ \\ ${ }^{1}$ Department of Animal Science, Faculty of Agriculture, University of Ondokuz Mayis, 55270 Samsun, Turkey \\ *Corresponding author

\begin{tabular}{l|l} 
A R T I C L E I N F O & A B S T R A C T \\
$\begin{array}{l}\text { Research Article } \\
\text { Received : 23/04/2020 } \\
\text { Accepted : 25/09/2020 }\end{array}$ & $\begin{array}{l}\text { The aim of this study was to reveal the association of alizarin test scores (ATS) with somatic cell } \\
\text { scores (SCC) in bovine milk. The milk samples (n=60) were collected from three milk selling points } \\
\text { in Samsun province of Turkey in two test days (TD). To obtain ATS, change of colour in milk after } \\
\text { adding dye solution were used (ATS 1: red-brown/normal, ATS 2: yellow/acidic, and ATS 3: } \\
\text { violet/alkali). To test for reliability of ATS by acidity, pH values of the samples were measured } \\
\text { with a standard pH meter. In SCC analyses, direct microscopic cell counting was applied. Of } \\
\text { examined parameters, only SCC was differed by TD, and both pH and SCC were differed by the } \\
\text { location. According to ATP groups, pH and SCC means were also changed. Finally, estimated weak } \\
\text { (r=0.247) correlation coefficient between ATS and SCC pointed out that ATS data are not suitable } \\
\text { to detect quality degree of bovine milk samples. }\end{array}$ \\
Keywords: &
\end{tabular}

Cow milk

Acidity

Somatic cell count

Milk quality

Milk analysis

\section{Introduction}

As well known, cattle has the main role in milk production throughout the world. However, in addition to boosting the amount of the total production, elevating the nutritional value and hygienic quality of milk has a particular importance. In spite of the bacteriological test has been assumed to be the most reliable technique for hygienic quality, more practical methods on detecting the quality level of raw milk are still needed.

California mastitis test, somatic cell counting, electrical conductivity of milk (Kasikci et al., 2012) and enzyme activity evaluation (Atasever et al.,2011) have widely been performed as alternative methods to determine milk quality. Of these, somatic cell count (SCC), which passes from blood to milk during the udder infection to combat microorganisms, has relatively high correlation with total bacteria count (TBC) and commonly used to detect an abnormality in milk. The EU Directives (46/92 and 71/94) declared a limit for SCC as $400 \times 10^{3}$ cells $/ \mathrm{ml}$ that reflects the highest threshold of cow milk for human consumption (Atasever et al. 2011). Financial losses because of high SCC were calculated as $\$ 217.8$ per milking cow in Turkey conditions (Atasever and Erdem, 2009). In addition to these, using acidity level of milk for this aim is still been argued. Some acidity tests such as $\mathrm{pH}$ and titration method (Kirdar, 2011) are the main techniques to determine milk acidity. Atasever et al. (2010) estimated a weak correlation $(\mathrm{r}=0.20)$ between SCC and pH of milk. Similarly, Kandeel et al. (2019) reported that $\mathrm{pH}$ does not ensure a clinically useful cow-side screening method for predicting subclinical mastitis or udder infection in lactating dairy cows. Also, Baran and Adiguzel (2020) calculated a negative correlation between $\mathrm{pH}$ and titration acidity level in cow milk. Machado et al. (2017) indicated to change of ionic properties of milk with higher $\mathrm{pH}$. In addition to these reflectors, alizarin indicator test has been stated as another alternative method to decide milk acidity level (Kirdar, 2001). However, there is no sufficient information on whether this method is reliable for detecting milk quality or not. Revealing the possibility of alizarin test scores (ATS) for assessing the abnormality of milk will ensure a rapid and fast opportunity to dairy owners.

The objective of the present study was to determine the relations of ATS data with SCC that used as a reliable parameter for detecting milk quality level in cow milk. 


\section{Materials and Methods}

The main materials of this study were raw milk samples collected from three local bazaars (Istasyon, Gebi and Atakum) of Samsun province of Turkey. In two test days (TD), ten samples which including $50 \mathrm{ml}$ per sample were taken and transferred to the laboratory with plastic bags in the same days for tests. The samples were preserved with ice-box until analyses. Three assays with plastic tubes those including $10 \mathrm{ml}$ milk for each sample were prepared from the initial samples. The samples were heated to $20^{\circ} \mathrm{C}$ in a warm water bath. The SCC analysis was performed using direct microscopic cell counting (Atasever et al., 2010). In this analysis, $0.01 \mathrm{~mL}$ milk sample was transmitted to a slide and fitted into a square with $1 \mathrm{~cm}^{2}$. After dying this area with methylene blue solution, counting process was performed in at least 20 sights. To ensure homogeneity of the variance, all SCC values were converted to $\log 10$ base in the statistical analyses.

The $\mathrm{pH}$ values of the samples were obtained using a standard $\mathrm{pH}$ meter. In evaluation, $\mathrm{pH}$ values between 6.50 and 6.59 were noted as normal, $\mathrm{pH}<6.50$ were acidic and $\mathrm{pH}>6.60$ were alkali (Kirdar, 2001).

To obtain ATS, change of colour in milk after adding alizarin dye solution was used. For this, $2 \mathrm{ml}$ milk and $2 \mathrm{ml}$ alizarin dye solution (red/brown coloured) was mixed into a standard tube. No change on the colour and any coagulation was assessed to be normal (ATS $=1$ ). A strong coagulation with yellow colour was noted as acidic $(\mathrm{ATS}=2)$ and a weak coagulation with violet colour was recorded as alkali (ATS=3). Effects of TD on the parameters were tested by Independent Simple t-test. To evaluate milk selling points (locations) on the parameters were analysed by One-way ANOVA and differences among the groups were tested by Duncan's multiple range test. The linear model used in the study was as follows:

$$
\mathrm{y}_{\mathrm{ij}}=\mu+\mathrm{a}_{\mathrm{i}}+\mathrm{e}_{\mathrm{ij}}
$$

Where; $y_{i j}$ is the observation value, $\mu$ is the overall mean, $a_{i}$ is effect of location ( $i=1,2$ and 3$)$ and $e_{i j}$ is random error.
To reveal the relations of ATS with $\mathrm{pH}$ and $\operatorname{logSCC}$, Kendall's tau-b correlation coefficients were estimated. To obtain clear evaluation, ATS 2 and 3 values were combined to same group as abnormal values (normal ATS values had been coded as 1 and the abnormal ones were coded as 2). All statistical analyses were performed using SPPS.17 packet program at the 0.05 significance level.

\section{Results and Discussion}

Change of ATS, $\mathrm{pH}$ and $\operatorname{logSCC}$ according to TD is shown in Table 1. Although all means of the first TD higher than the second ones, only $\operatorname{logSCC}$ means were different from each other $(\mathrm{P}<0.05)$. Normally, day to day variation in SCC values might be assumed to be unexpected result. As a matter of fact, Erdem et al. (2012) and Yalcin and Atasever (2018) reported this variation in SCC of bovine milk.

Examined parameters were also evaluated by the location or milk selling points. As seen in Table 1, $\mathrm{pH}$ and $\operatorname{logSCC}$ means were differed by the location $(\mathrm{P}<0.05)$. Obtained ATS means pointed out to acidic situation the milk samples. Really, calculated $\mathrm{pH}$ values were lower than 6.50 and this case was found as harmonic with ATS values. For locations, milk samples belonging to Istasyon bazaar had relatively lower acidity $(\mathrm{P}<0.05)$ according to $\mathrm{pH}$ means $(p H=6.17)$. However, milk samples collected from the other two locations had similar $\mathrm{pH}$ means. Also, the overall mean of $\mathrm{pH}$ was calculated to be $5.92 \pm 0.06$. This mean was lower than that determined from $\mathrm{pH}$ of the milk samples $(6.54 \pm 0.01)$ collected from the same region in an earlier study (Atasever et al., 2010).

Similar to TD groups, significant differences $(\mathrm{P}<0.05)$ were calculated among the $\operatorname{logSCC}$ means by locations. Accordingly, milk samples belonging to Istasyon had the lowest $\operatorname{logSCC}$ and this mean was different from that determined in Atakum, statistically. In another study conducted in Samsun province (Keskin and Atasever, 2013), $\log$ SCC of milk sold in Gebi was lower than that sold in Istasyon. This finding points out to inconstant characteristic of SCC of milk by year and location even though the milk has been belonging to same province.

Table 1. Factors affecting examined parameters

\begin{tabular}{l|cccc}
\hline \multicolumn{1}{c|}{ Test day } & $\mathrm{n}$ & $\mathrm{ATS}$ & $\mathrm{pH}$ & $\operatorname{logSCC}$ \\
\hline 1 & 30 & $1.93 \pm 0.12$ & $5.96 \pm 0.09$ & $6.02 \pm 0.07^{\mathrm{b}}$ \\
2 & 30 & $1.83 \pm 0.12$ & $5.87 \pm 0.09$ & $5.82 \pm 0.06^{\mathrm{a}}$ \\
\hline \multicolumn{1}{c|}{ Location } & & & & \\
\hline İstasyon & 20 & $2.10 \pm 0.14$ & $6.17 \pm 0.09^{\mathrm{b}}$ & $5.81 \pm 0.06^{\mathrm{a}}$ \\
Gebi & 20 & $1.85 \pm 0.15$ & $5.84 \pm 0.12^{\mathrm{a}}$ & $5.87 \pm 0.09^{\mathrm{ab}}$ \\
Atakum & 20 & $1.70 \pm 0.16$ & $5.75 \pm 0.12^{\mathrm{a}}$ & $6.09 \pm 0.04^{\mathrm{b}}$ \\
Overall & 60 & $1.88 \pm 0.08$ & $5.92 \pm 0.06$ & $5.92 \pm 0.04$ \\
\hline
\end{tabular}

Different superscript letters in the same line indicate statistically significant differences $(\mathrm{a}, \mathrm{b}: \mathrm{P}<0.05)$

Table 2. Change of $\mathrm{pH}$ and somatic cell count (logSCC) by alizarin test scores (ATS)

\begin{tabular}{l|ccc}
\hline \multicolumn{1}{c|}{ ATS groups } & $\mathrm{n}$ & $\mathrm{pH}$ & $\operatorname{logSCC}$ \\
\hline Normal & 31 & $6.14 \pm 0.06^{\mathrm{B}}$ & $5.81 \pm 0.05^{\mathrm{a}}$ \\
Abnormal & 29 & $5.68 \pm 0.11^{\mathrm{A}}$ & $6.04 \pm 0.07^{\mathrm{b}}$ \\
Overall & 60 & $5.92 \pm 0.06$ & $5.92 \pm 0.04$ \\
\hline
\end{tabular}

Different superscript letters in the same line indicate statistically significant differences $(\mathrm{a}, \mathrm{b}: \mathrm{P}<0.05 ; \mathrm{A}, \mathrm{B}: \mathrm{P}<0.01)$ 


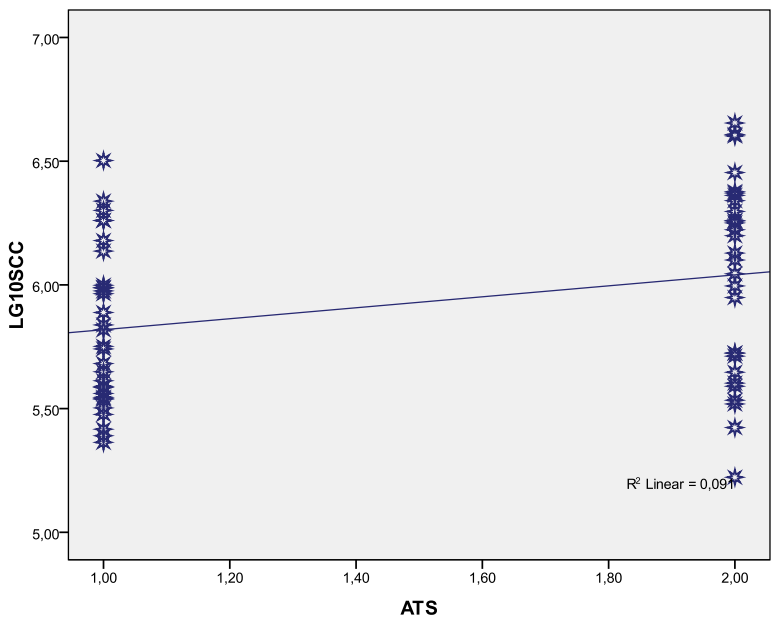

Figure 1. Relations of alizarin test scores (ATS) with somatic cell count $(\log \mathrm{SCC})$

ATS values were divided to two groups to be normal and abnormal thresholds by the colour status of milk samples (Table 2). As seen, both $\mathrm{pH}(\mathrm{P}<0.01)$ and $\operatorname{logSCC}$ $(\mathrm{P}<0.05)$ means were different by ATS groups. Interestingly, all pH means were lower than 6.50 and this case clearly indicated that $\mathrm{pH}$ values of the samples had a high acidity. However, for normal ATS group, $\mathrm{pH}$ mean relatively elevated. Similar inclining was obtained in $\operatorname{logSCC}$ means. Such that, in the normal ATS group, $\operatorname{logSCC}$ mean was lower $(\mathrm{P}<0.05)$ than that obtained in the second group. This case might be assumed as an expected result. Besides, calculated overall mean $(1193100 \pm 132304$ cells $/ \mathrm{ml}$ ) of the samples was found more than double according to threshold limit $\left(500 \times 10^{3}\right.$ cells $\left./ \mathrm{ml}\right)$ of SCC declared by Turkish Food Codex (Yalcin and Atasever, 2018). Interestingly, SCC was estimated to be $636 \times 10^{3}$ cells $/ \mathrm{ml}$ in an initial study that conducted in the same area (Atasever et al., 2010). These cases reflect that milk sold at these points had serious problems by SCC or quality.

The relations of ATS values with $\mathrm{pH}$ and SCC were also investigated. Accordingly, Kendall's tau-b correlation coefficient of ATS and $\mathrm{pH}$ was estimated to be negative and weak $(r=-0.285)$. The negative correlation of two parameters may be explained by the dropping tendency of pH (turning to high acidity) with elevated ATS (abnormal ATS values). Really, ATS values correspondingly increased with $\operatorname{logSCC}$ (Fig.1) but, estimated correlation coefficient $(r=0.247)$ between ATS and $\operatorname{logSCC}$ was found to be weak.

\section{Conclusions}

The reliability of ATS values on raw milk quality detection was examined in this study. Weak associations were calculated between ATS and $\mathrm{pH}$ or SCC. At this context, ATS data are not found to be reliable to determine acidity level (by $\mathrm{pH}$ ) and also quality degree (by SCC) in bovine raw milk samples. However, further investigations using more sample size are advised to confirm the findings of the present study.

\section{Acknowledgements}

The present study has been designed from a part of the master thesis of the first author.

\section{References}

Atasever S, Erdem H. 2009. Estimation of milk yield and financial losses related to somatic cell count in Holstein cows raised in Turkey. J. Anim. Vet. Adv., 8(8): 1491-1494.

Atasever S, Erdem H, Altop A. 2010. Relationships between milk somatic cell count and $\mathrm{pH}$ in dairy cows. J. Anim. Vet. Adv. 9(11):1575-1577.

Atasever S, Erdem H, Kul E. 2011. Relationship between somatic cell count and catalase activity in raw milk of Anatolian buffaloes. Sci. Res. Essays, 6 (19): 4109-4112.

Baran A, Adiguzel MC. 2020. Some physicochemical and microbiological properties of cow milks collected from local dairy delicatessens in Erzurum, Turkey. KSU J. Agric. Nat., 23 (2): 493-505.

Erdem H, Atasever S, Kul E. 2012. Effects of milk age and storage temperature on somatic cell count of bovine milk: A case study from Turkey. J. Anim. Plant Sci., 22(4): 884-887.

Kandeel SA, Megahed AA, Ebeid MH, Constable PD. 2019. Ability of milk $\mathrm{pH}$ to predict subclinical mastitis and intramammary infection in quarters from lactating dairy cattle. J. Dairy Sci., 102 (2): 1417-1427.

Kasikci G, Cetin O, Bingol EB, Gunduz MC. 2012. Relations between electrical conductivity, somatic cell count, California mastitis test and some quality parameters in the diagnosis of subclinical mastitis in dairy cows. Turk. J. Vet. Anim. Sc., 36 (1): 49-55.

Kırdar S. 2001. Analysis Methods in Milk and It's Products. Suleyman Demirel University Publication No: 18, 195 pages., Isparta, Turkey (in Turkish).

Machado SC, Fischer V, Stumpf MT, Stivanin SCB. 2017. Seasonal variation, method of determination of bovine milk stability, and its relation with physical, chemical, and sanitary characteristics of raw milk. Rev. Bras. Zootec., 46(4): 340-347.

Yalcin BK, Atasever S. 2018. Relationships between dye reduction test scores and somatic cell count in bovine raw milk. Turk. J. Agric. Food Sci. Technol., 6 (5): 557-560. 